\title{
A haemagglutination test for anti-Panton-Valentine leucocidin in serum: an interim report on 200 cases
}

\author{
A. G. TOWERS \\ From the Department of Pathology, Institute of Orthopaedics, Royal National \\ Orthopaedic Hospital, Stanmore, Middlesex
}

SYNOPSIS The test is an application of the method originally described by Boyden (1951) and adapted by Stavitsky and Arquilla (1958). Sera which contain anti-Panton-Valentine leucocidin agglutinate the prepared red cells, often to a very high dilution, and this has provided a useful serological test for the diagnosis of staphylococcal disease in orthopaedic lesions. The test is quicker as a routine investigation than the bioscopic method previously described by Towers and Gladstone (1958).

\section{MATERIALS AND METHOD}

SHEEP CELLS Defibrinated blood or cells taken into Alsever's solution are suitable. The cells are thrice washed in saline and used only if the third washing shows no haemolysis. Packed cells, $0.5 \mathrm{ml}$., are made up to about $20 \mathrm{ml}$. in buffered saline $p \mathrm{H} 7 \cdot 2$ and adjusted so that $1 \mathrm{ml}$. suspension $+9 \mathrm{ml}$. ammoniated water give a reading of 30 on an Eel photoelectric colorimeter. These standardized cells are ready for tannic acid treatment but will keep for 24 hours at $4^{\circ} \mathrm{C}$.

BUFFERED SALINE Buffered salines at $p \mathrm{H} 6.4$ and 7.2 are made by mixing $100 \mathrm{ml}$. sterile saline with $100 \mathrm{ml}$. of the appropriate $0.15 \mathrm{M}$ buffer.

N/100 NORMAL RABBIT SERUM Normal rabbit serum, $1 \mathrm{ml}$. in $100 \mathrm{ml}$. sterile saline.

TANNIC ACID Stock $1 \%$ Merck reagent grade. Store at $4^{\circ} \mathrm{C}$. Dilute $1: 20,000$ in saline for use.

LEUCOCIDIN The crude concentrate of Panton-Valentine leucocidin was kindly supplied by Gladstone and Woodin at Oxford. It was used in the concentration of 50L. + units $/ \mathrm{ml}$. in the proportion of $0.02 \mathrm{ml}$. to $16 \mathrm{ml}$. tanned erythrocytes.

SERA These were inactivated at $56^{\circ} \mathrm{C}$. for 20 minutes before use.

PREPARATION OF TANNED CELlS Standardized sheep cells, $16 \mathrm{ml}$., and $16 \mathrm{ml}$. 1:20,000 tannic acid are mixed and left at $4^{\circ} \mathrm{C}$. for 30 minutes, then centrifuged gently, washed with $16 \mathrm{ml}$. pH 7.2 buffered saline, and resus-

Received for publication 24 May 1960. pended in $16 \mathrm{ml}$. saline. It is important to spin gently at all stages of preparation of the erythrocytes to ensure a final even resuspension of sensitized cells.

SENSITIZATION OF TANNED CELls. Buffered saline, $64 \mathrm{ml}$. at $p \mathrm{H} 6.4$, and $0.02 \mathrm{ml}$. Panton-Valentine leucocidin crude concentrate and $16 \mathrm{ml}$. tanned red cells are mixed in that order and kept on the bench for 15 minutes. The cells are centrifuged gently, washed once with $32 \mathrm{ml}$. $\mathrm{N} / 100$ normal rabbit serum and resuspended in $16 \mathrm{ml}$. $\mathrm{N} / 100$ normal rabbit serum ready for use.

HAEMAGgLUTINATION TEST Test tubes of $3 \times \frac{1}{2}$ in. are used, and $0.5 \mathrm{ml}$. quantities in a dilution of 1 in 1,000 to 1 in 256,000 using $N / 100$ normal rabbit serum as the diluent for the inactivated sera are set up. A known serum control is included in each batch and two tubes containing $0.5 \mathrm{ml}$. diluent only.

Sensitized cells, $0.06 \mathrm{ml}$., are added to each of the nine tubes in each test row, and to the two control tubes of diluent. The rack is well shaken and left on the bench overnight. The tubes are read over a concave mirror and graded according to the pattern formed by the agglutinated cells, in which $\mathrm{O}=$ smooth round button of cells; $+=$ crenated button or a heavier ring round each button with a smooth interior; $++=$ definite agglutination, or with a heavier peripheral ring than in + ; $+++=$ discrete granular agglutination or a folded edge to mat. The titre is the last tube to show a positive result. Perspex racks or flat-bottomed tubes are unsuitable, as no consistent pattern is obtained.

RESULTS

The results on the 25 sera estimated by both the 
bioscopic and haemagglutination methods are shown in Table I.

\section{TABLE I}

COMPARISON OF BIOSCOPIC AND HAEMAGGLUTINATION METHODS

\begin{tabular}{ll} 
Bioscopic Method & Haemagglutination Method \\
\hline Normal range up to 10 & Titre of 8 or less \\
12 sera & 10 sera $(+2$ sera giving titre 16) \\
Raised values over 10 & Titre of 16 or over \\
13 sera & 12 sera $(+1$ serum with titre of 8$)$
\end{tabular}

The haemagglutination test results on the 200 sera are given in Table II, and are shown in relation to the anti- $\alpha$ haemolysin test, which is the most widely accepted serological test for staphylococcal disease.

TABLE II

RESULTS ON 200 SERA ESTIMATES FOR ANTIPANTON-VALENTINE LEUCOCIDIN COMPARED WITH ANTI- $a$ HAEMOLYSIN

\begin{tabular}{|c|c|c|}
\hline $\begin{array}{l}\text { Anti-Panton- } \\
\text { Valentine } \\
\text { Leucocidin } \\
\text { (serum titre) }\end{array}$ & $\begin{array}{l}\text { Anti- a Haemolysin } \\
\text { (normal value) }\end{array}$ & $\begin{array}{l}\text { Anti- a Haemolysin } \\
\text { (values above } 2 \text { units) }\end{array}$ \\
\hline $\begin{array}{l}\text { Group I } \\
1 \text { or less }\end{array}$ & $\begin{array}{l}30 \text { sera } \\
14 \text { miscellaneous } \\
10 \text { normal controls } \\
4 \text { bone tuberculosis } \\
2 \text { bone tumours }\end{array}$ & $\begin{array}{l}\text { I serum } \\
\text { osteomyelitis }\end{array}$ \\
\hline \multirow[t]{2}{*}{$\begin{array}{l}\text { Group II } \\
8 \text { or less }\end{array}$} & $\begin{array}{l}67 \text { sera } \\
31 \text { miscellaneous }\end{array}$ & $\begin{array}{l}11 \text { sera } \\
4 \text { tuberculosis with } \\
\text { secondary staphylococ- } \\
\text { col infection }\end{array}$ \\
\hline & $\begin{array}{l}10 \text { normal controls } \\
10 \text { tuberculosis } \\
4 \text { malignant disease } \\
12 \text { chronic osteomyelitis }\end{array}$ & 7 chronic osteomyelitis \\
\hline $\begin{array}{l}\text { Group III } \\
16 \text { or over }\end{array}$ & $\begin{array}{l}16 \text { sera } \\
5 \text { osteomyelitis }\end{array}$ & $\begin{array}{l}39 \text { sera } \\
1 \text { normal control (recent } \\
\text { boils) }\end{array}$ \\
\hline & $\begin{array}{l}2 \text { malignant disease } \\
9 \text { still under investi- } \\
\text { gation; } 6 \text { probably } \\
\text { osteomyelitis }\end{array}$ & 38 osteomyelitis \\
\hline
\end{tabular}

It will be seen that of the total 200 sera examined, 69 were from cases of osteomyelitis; of these 69 cases, $49(71 \%)$ gave an end-point at a dilution of 1 in 16,000 or over. The 19 chronic cases in Group II were all of long standing admitted for orthopaedic surgery.

Acute osteomyelitis, or a flare-up of old disease, seems to be reflected in the higher titres of antiPanton-Valentine leucocidin, the exception being so far serum obtained from a child from whom a staphylococcus was recovered subsequently from the spine. The anti- $\alpha$ haemolysin in this case rose quickly to 16 to 20 units $/ \mathrm{ml}$. without any detectable
anti-Panton-Valentine leucocidin over three months, and the Staph. pyogenes itself has since been shown to produce no Panton-Valentine leucocidin.

The usefulness of an additional test for staphy은 lococcal disease in cases where material has not beere available for bacteriology has already been stresseof (Towers and Gladstone, 1958). Figs. 1 and 2 show

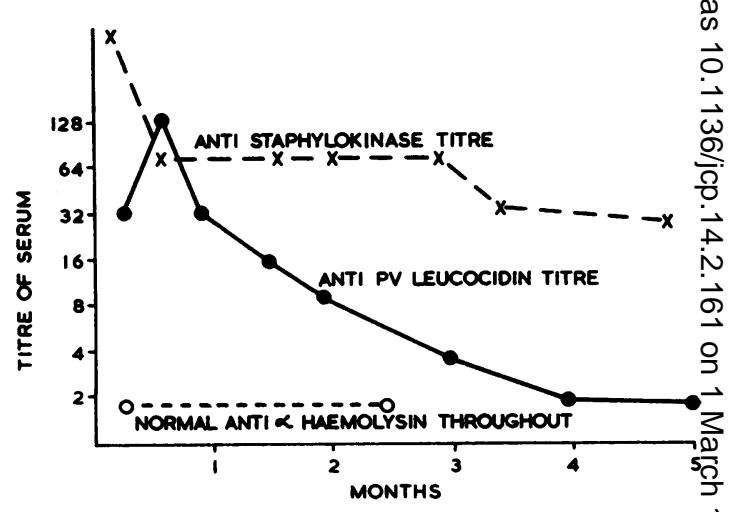

FIG. 1. A man aged 40, with destructive lesion at $D 10 \Omega$ No material was available for culture.

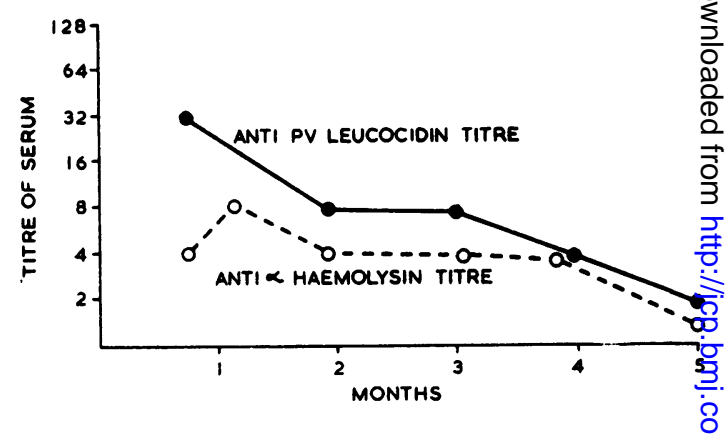

FIG. 2. Case 2. A woman, aged 33, for 10 months suffere backache and for one month acute pain. No material was available for culture.

how the haemagglutination estimation has helpedy in the diagnosis of two cases of spinal osteomyelitis of unknown origin.

In both cases there was a history of back pain fơp several months before admission as tuberculoug spine. In one the anti- $a$ haemolysin remained at nofe mal levels throughout the five-month stay in hospita in the other there was a rise of 4 units $/ \mathrm{ml}$. with $\vec{a}$ gradual return to normal. In both the anti-PantonValentine leucocidin titres were raised on admissio ${ }^{+}$ and showed a gradual return to normal.

The obvious criticism of the method presente\& here is that a crude extract of Panton-Valentine leucocidin has been used as a sensitizing agent, and 
the results given as the end-point of the dilution of serum, but this is an interim report only.

Woodin (1959) has now shown that anti-PantonValentine leucocidin is separable into two fractions, the fast and slow-moving components, and gives the method for their preparation and separation. Tests so far made with these purified components have shown that the results obtained with slow-component sensitized erythrocytes gives titres similar but lower than those obtained using the crude extract.

It is hoped to follow this series with another, in which the purified slow component is used as the sensitizing antigen. In view of the increasing widespread interest in staphylococcal disease it would be highly desirable to have a standard preparation of Panton-Valentine leucocidin generally available. This would enable comparative data on anti-Panton-
Valentine leucocidin to be collected from various forms of staphylococcal disease.

It is a pleasure to thank Dr. G. P. Gladstone and Dr. A. M. Woodin for gifts of crude concentrates of PantonValentine leucocidin and fast and slow components of the more purified extract; Dr. H. Schwabacher of Watford who very kindly undertook the independent estimation of the 25 sera by the bioscopic method: and finally to Dr. C. H. Lack for continued interest and help in the preparation of this report.

\section{REFERENCES}

Boyden, S. V. (1951). J. exp. Med., 93, 107.

Stavitsky, A. B., and Arquilla, E. R. (1958). Int. Arch. Allergy, 13, 1. Towers, A. G., and Gladstone, G. P. (1958). Lancet, 2, 1192.

Woodin, A. M. (1959). Biochem. J., 73, 225. 